\title{
PEMETAAN DAERAH POTENSIAL BUDIDAYA TIRAM MUTIARA (PINCTADA MAXIMA) MENGGUNAKAN CITRA SATELIT BERDASARKAN PARAMETER HIDROMETEOROLOGI TERHADAP POLA MUSIMAN DI PERAIRAN LOMBOK, NUSA TENGGARA BARAT
}

\author{
Abdul Hamid Al Habib ${ }^{1}$,Anisatul Wahyuning Fitri ${ }^{2}$, Ni Putu Febry Anggraeni ${ }^{3}$, Dedi \\ Sucahyono ${ }^{4}$ \\ ${ }^{1,2,3,4}$ Program Studi Meteorologi Sekolah Tinggi Meteorologi Klimatologi dan Geofisika \\ Jl. Perhubungan I-Pondok Betung, Tanggerang Selatan 15221 \\ E-mail: abdulhamidalhabib96@gmail.com
}

\begin{abstract}
Pearl oysters (Pinctada maxima) is one of the potential economic resources of the sea but its supply from nature is not comparable with the rapid market needs for this product, so the population of pearl oysters is depleting and the price continues to increase. To overcome these problems can be done with cultivation and the selection of the right location supported by hydrometeorological parameters that match the quality standards for marine biota is one factor that influences the success of cultivation. The cultivation of pearl oysters is one of the potential waters in Indonesia, especially in the waters of Lombok. The purpose of this study was to analyze hydrometeorological parameters (current velocity, sea surface temperature, and salinity) and their influence on potential areas for the cultivation of pearl oysters based on seasonal patterns in the waters of Lombok, West Nusa Tenggara. This study utilizes satellite image data from January 2006 to December 2016. The method used is to classify each hydrometeorological parameter based on scoring, then each parameter is overlaid so that the highest score is obtained which indicates the most potential area for the cultivation of pearl oysters. The results showed that in general in the waters of Lombok, West Nusa Tenggara was included as a potential location for the cultivation of pearl oysters. The parameters used as references are in the good range for the growth and development of Pearl oysters in the waters of Lombok, West Nusa Tenggara.
\end{abstract}

Keywords: pearl oysters, Lombok waters, satellite images, hydrometeorological parameters, scoring

\begin{abstract}
Abstrak: Tiram mutiara (Pinctada maxima) merupakan salah satu sumber daya laut yang berpotensi ekonomi tinggi tetapi persediaannya dari alam tidak sebanding dengan pesatnya kebutuhan pasar untuk produk ini, sehingga populasi tiram mutiara makin menipis dan harganya pun terus meningkat. Untuk menanggulangi permasalahan tersebut dapat dilakukan dengan usaha budidaya dan pemilihan lokasi yang tepat dengan didukung parameter hidrometeorologi yang sesuai baku mutu untuk biota laut adalah satu faktor yang berpengaruh dalam keberhasilan usaha budidaya. Usaha budidaya tiram mutiara merupakan salah satu potensi perairan di Indonesia khususnya di wilayah Perairan Lombok. Tujuan dari penelitian ini adalah untuk menganalisis parameter hidrometeorologi (kecepatan arus, suhu permukaan laut, dan salinitas) serta pengaruhnya terhadap daerah potensial untuk budidaya tiram mutiara berdasarkan pola musiman di Perairan Lombok, Nusa Tenggara Barat. Penelitian ini memanfaatkan data citra satelit pada bulan Januari 2006 hingga bulan Desember 2016. Metode yang digunakan yaitu dengan mengklasifikasikan setiap parameter hidrometeorologi berdasarkan scoring, kemudian masing-masing parameter di overlay sehingga akan didapatkan skor tertinggi yang mengindikasikan daerah paling potensial untuk budidaya tiram mutiara. Hasil penelitian menunjukkan bahwa secara umum di Perairan Lombok, Nusa Tenggara Barat termasuk sebagai lokasi yang potensial untuk budidaya tiram mutiara. Parameter-parameter yang dijadikan acuan berada pada kisaran baik untuk pertumbuhan dan perkembangan tiram Mutiara di Perairan Lombok, Nusa Tenggara Barat.
\end{abstract}


Kata kunci: tiram mutiara, Perairan Lombok, citra satelit, parameter hidrometeorologi, scoring

\section{PENDAhuluan}

Indonesia merupakan negara yang sangat kaya akan sumber daya alam yang beragam dan tersebar di seluruh nusantara. Salah satu sumber daya alam yang sangat diminati dan memiliki harga jual yang tinggi adalah tiram mutiara (Pinctada maxima). Tiram mutiara (Pinctada maxima) merupakan salah satu biota laut yang hampir semua bagian dari tubuhnya mempunyai nilai jual, baik mutiara, cangkang, daging dan organisme tiram itu sendiri (benih maupun induk) (Spj, 2007).

Tiram mutiara termasuk dalam phylum mollusca, phylum ini terdiri atas 6 klas yaitu: Monoplancohora, Amphineura, Gastropoda, Lamellibrachiata, atau Pellecypoda, Seaphopoda, dan Cephalopoda. Tiram merupakan hewan yang mempunyai cangkang yang sangat keras dan tidak simetris. Hewan ini tidak bertulang belakang dan bertubuh lunak (Philum mollusca).Klasifikasi tiram mutiara sebagai berikut:

$\begin{array}{ll}\text { Kingdom } & \text { : Animalia } \\ \text { Sub kingdom: } & \text { Invertebrata } \\ \text { Philum } & : \text { Mollusca } \\ \text { Klas } & : \text { Pellecypoda } \\ \text { Ordo } & : \text { Anysomyaria } \\ \text { Famili } & : \text { Pteridae } \\ \text { Genus } & : \text { Pinctada } \\ \text { Spesies } & : \text { Pinctada maxima }\end{array}$

Jenis-jenis tiram mutiara yang terdapat di Indonesia adalah Pinctada maxima, Pinctada margaritifera, Pinctada fucata, Pinctada chimnitzii, dan Pteria penguin. Sebagai penghasil mutiara terpenting adalah tiga spesies yaitu, Pinctada maxima, Pinctada margaritifera dan Pinctada martensii. Sebagai jenis yang ukuran terbesar adalah Pinctada maxima (Sutaman, 2000).

Wilayah Indonesia yang memiliki potensi yang besar untuk perkembangbiakan tiram mutiara (Pinctada maxima) adalah wilayah Indonesia bagian timur seperti Irian Jaya, Sulawesi dan gugusan laut Arafuru (Spj, 2007) dan lokasi budidaya tiram mutiara (Pinctada maxima) yang telah berkembang dengan baik berada di Maluku, Sulawesi, Nusa Tenggara, Lampung dan Bali (Kotta, 2018). Meskipun sudah cukup banyak wilayah di Indonesia yang membudidayakan tiram mutiara (Pinctada maxima) ini, namun masih terdapat kekurangan benih dalam pembudidayaannya. Selama ini, masyarakat hanya memanfaatkan benih dari alam yang mana jumlahnya sangat fluktuatif, tergantung musim, dan ukurannya tidak seragam dan sesuai standar untuk diambil sehingga membutuhkan waktu dan tambahan biaya dalam hal pemeliharaannya untuk mencapai ukuran yang standar. Pembudidayaan dengan menggunakan benih dari alam ini dapat menyebabkan jumlah benih di alam akan semakin berkurang dan menyebabkan menurunnya produksi tiram mutiara.

Mutiara air laut menjadi salah satu kekayaan komoditas khas Lombok, Nusa Tenggara Barat, yang dikenal hingga luar negeri. Jenis kerang yang banyak dibudidayakan di pulau ini adalah spesies Pinctada maxima atau biasa dikenal sebagai ratu mutiara.

Dengan memperhatikan beberapa parameter hidrometeorologi seperti suhu permukaan laut, kecepatan arus, dan salinitas di perairan, dapat diperoleh informasi lokasi perairan yang tepat sebagai lokasi pembenihan tiram mutiara (Pinctada maxima). Dalam pembangunan lokasi pembudidayaan tiram mutiara (Pinctada maxima) harus memperhatikan banyak faktor, utamanya kondisi perairan yang sesuai. Kondisi perairan yang sesuai akan mendukung serta meningkatkan hasil budidaya tiram mutiara ini sendiri. 
Tujuan penelitian ini adalah untuk mengetahui lokasi yang paling baik untuk pembudidayaan tiram mutiara (Pinctada maxima) di wilayah Lombok, Nusa Tenggara Barat berdasarkan parameter hidrometeorologi (kecepatan arus, suhu permukaan laut, dan salinitas). Hasil penelitian ini diharapkan dapat memberikan informasi serta menjadi acuan dalam pembangunan lokasi budidaya tiram Mutiara agar semakin baik prospek kedepannya.

\section{METODE PENELITIAN}

Penelitian ini dilakukan di Perairan Lombok dengan memanfaatkan data citra satelit yaitu satelit Terra, Aqua, dan pemodelan untuk mendapatkan data parameter suhu permukaan laut (SST), kecepatan arus, dan salinitas. Data yang diambil mulai dari tahun 2006 sampai dengan 2016. Kemudian dianalisis menggunakan pemberian skor setiap nilai yang didapatkan berdasarkan klasifikasi yang telah dilakukan penelitian sebelumnya oleh Effendi (2003). Didapatkan daerah potensial secara umum sepanjang tahun, kemudian dianalisis lagi untuk mendapatkan musim atau masa yang paling cocok untuk budidaya tiram mutiara di Perairan Lombok, Nusa Tenggara Barat.

Kecepatan arus laut sebagai variabel primer, sedangkan suhu permukaan laut dan salinitas sebagai variabel sekunder (Kangkan, 2006). Kemudian dianalisis dan pemberian skor dengan mengunakan formula IF pada microsoft excel dengan klasifikasi sebagai berikut:

Tabel 1. Sistem Penilaian Kesesuaian Perairan untuk Lokasi Budidaya Tiram Mutiara

\begin{tabular}{lcccc}
\hline \multicolumn{1}{c}{ Parameter } & Kisaran & $\begin{array}{c}\text { Angka } \\
\text { Penilaian }\end{array}$ & Bobot & Sumber \\
\hline Kecepatan Arus & $16-25$ & 5 & 5 & \\
(cm/detik) & $10-15$ dan $26-30$ & 3 & & DKP (2002) \\
& $<10$ dan $>30$ & 1 & 3 & \\
Salinitas (ppt) & $32-35$ & 5 & 3 & Radiarta et al (2003) \\
& $28-31$ dan $36-38$ & 3 & & \\
Suhu permukaan laut & $<28$ dan $>38$ & 1 & 3 & DKP (2002) \\
$\left({ }^{\circ}\right.$ C) & $28-30$ & 5 & & \\
& $25-27$ dan $31-32$ & 3 & & \\
\hline Jumlah nilai maksimum & $<25$ dan $>32$ & 1 & & \\
parameter & $(5 \times 5+5 \times 3+5 \times 3)$ & 55 & & \\
\hline
\end{tabular}

Sumber: Modifikasi Kangkan (2006) dan Suryanto (2005)

Keterangan:

1. Bobot berdasarkan pengaruh parameter dominan

2. Skor berdasarkan range parameter

Perhitungan nilai kesesuaian bagi pengembangan aktivitas budidaya kerang mutiara menggunakan persamaan berikut (Yulianda 2007):

$$
\operatorname{IKK}=\sum\left(\frac{N i}{N \max }\right) \times 100 \%
$$

Keterangan :

IKK : Indeks kesesuaian Kawasan

$\mathrm{Ni}$ : bobot $\mathrm{x}$ skor

Nmax : Total skor 
Terakhir, data dipetakan dengan menggunakan QGIS untuk mendapatkan daerah potensial secara umum dan musim atau masa yang paling cocok sesuai dengan parameter kecepatan arus, suhu permukaan laut (SST), dan salinitas.

Hasil akhir dari analisis SIG melalui pendekatan overlay model adalah diperolehnya peringkat kelas kesesuaian kawasan untuk budidaya kerang mutiara. Kelas kesesuaian kawasan terdiri dari tiga kelas kesesuaian (Poernomo 1992; Bakosurtanal 1996) adalah:

1. Kelas S1 : Sangat sesuai (highly suitable)

Kawasan ini sangat sesuai untuk budidaya kerang mutiara tanpa adanya faktor pembatas yang berarti, atau memiliki faktor pembatas yang minor dan tidak akan menurunkan produktivitasnya secara nyata.

2. Kelas S2: Sesuai (suitable)

Kawasan ini mempunyai faktor pembatas yang berpengaruh terhadap produktivitas budidaya kerang mutiara. Pembatas ini akan meningkatkan masukkan/tingkatan perlakuan yang diperlukan.

3. Kelas S3: Tidak sesuai (not suitable) Selain itu kawasan ini mempunyai pembatas permanen dan berat sehingga sulit untuk diusahakan kegiatan budidaya kerang mutiara.

Selanjutnya untuk mendapatkan peta yang menggambarkan lokasi pengembangan budidaya dilakukan proses griding terhadap nilai skor dari keseluruhan variabel parameter fisika, kimia, dan biologi pada setiap koordinat. Proses ini disusun berdasarkan gabungan kelas kesesuaian yang setingkat (Tabel 2). Kemudian dilanjutkan dengan proses overlay untuk membentuk plot peta zona peruntukan budidaya kerang mutiara dengan bantuan software QGIS Sistem Informasi Geografis dapat digunakan untuk mempertimbangkan interaksi antara kegiatan budaya dan habitat sensitif (McKindsey 2006).

\begin{tabular}{cccc}
\hline No. & Kisaran nilai (Skor) & Tingkat kesesuaian & Evaluasi/Kesimpulan \\
\hline 1. & $85-100 \%$ & S1 & Sangat sesuai (highly suitable) \\
2. & $75-<85 \%$ & S2 & Sesuai (suitable) \\
3. & $<65-74 \%$ & S3 & Tidak sesuai (not suitable) \\
\hline
\end{tabular}

\section{Bahan}

1. Data suhu permukaan laut (SST) dari tahun 2006-2016. Didapatkan dari website coast watch NOAA.

2. Data kecepatan arus laut dan salinitas dari tahun 2006-2016. Didapatkan dari website marine copernicus

3. Data GIS Indonesia. Didapatkan dari website Badan Informasi Geospasial.

\section{Peralatan}

1. Perangkat lunak The Grid Analysis and Display System (GrADS) yang digunakan untuk membaca file dengan ekstensi .nc (netCDF).

2. Perangkat lunak Panoply untuk mengubah .nc menjadi .txt.

3. Perangkat lunak Microsoft Excel yang digunakan untuk analisis dan pemberian skor.

4. Perangkat lunak QGIS untuk analisis pemetaan daerah potensial. 


\section{Diagram Alir}

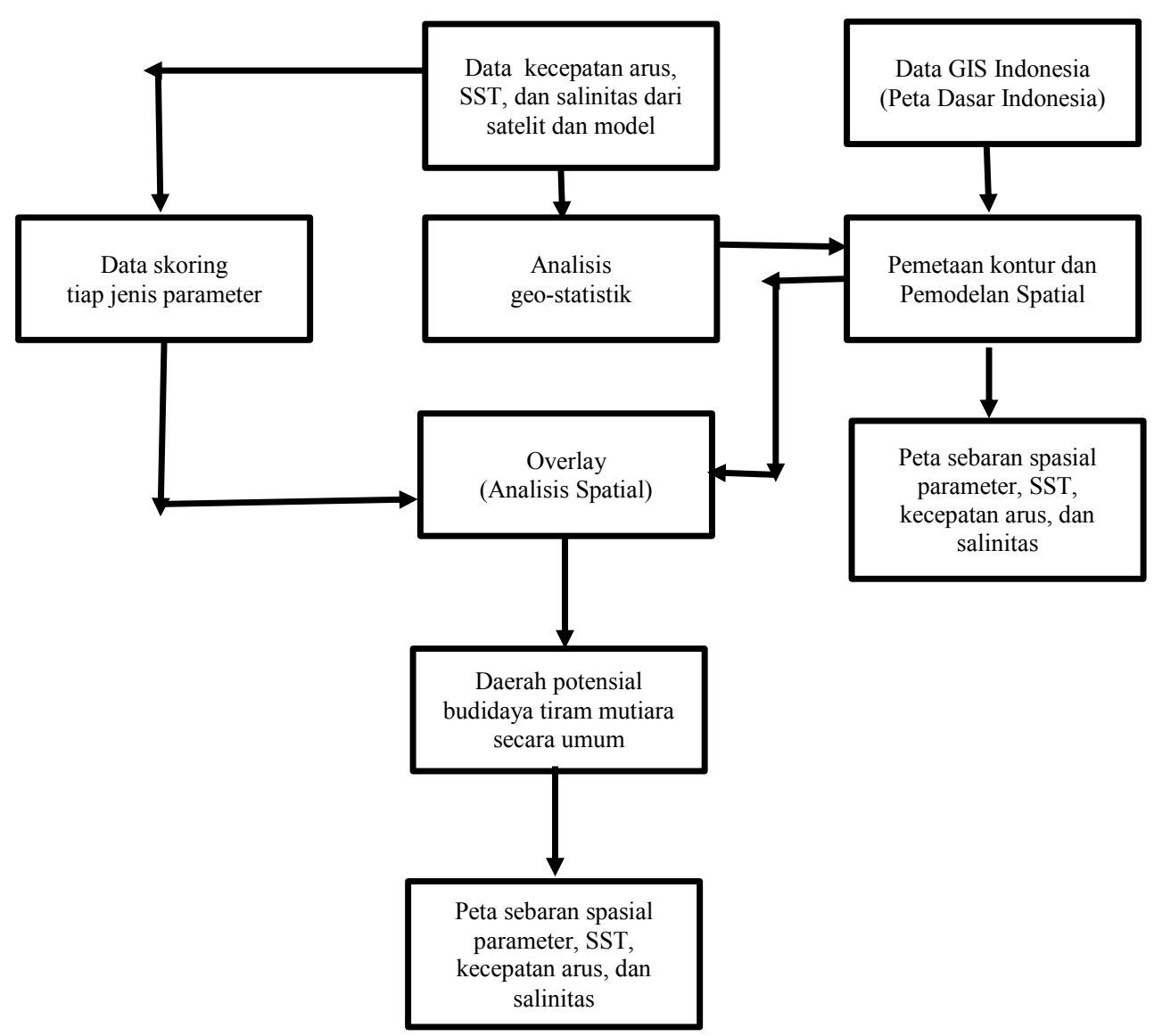

Gambar 1. Diagram Alir Penelitian

\section{Lokasi Penelitian}

Lokasi penelitian adalah Perairan di sekitar Pulau Lombok atau daerah Pesisir Pulau Lombok. Wilayah tersebut memiliki koordinat $115^{\circ} 45^{\prime} 00^{\prime \prime}-116^{\circ} 45^{\prime} 00^{\prime \prime}$ BT $08^{\circ} 15^{\prime} 00^{\prime \prime}-08^{\circ} 48^{\prime} 00^{\prime \prime}$ LS.

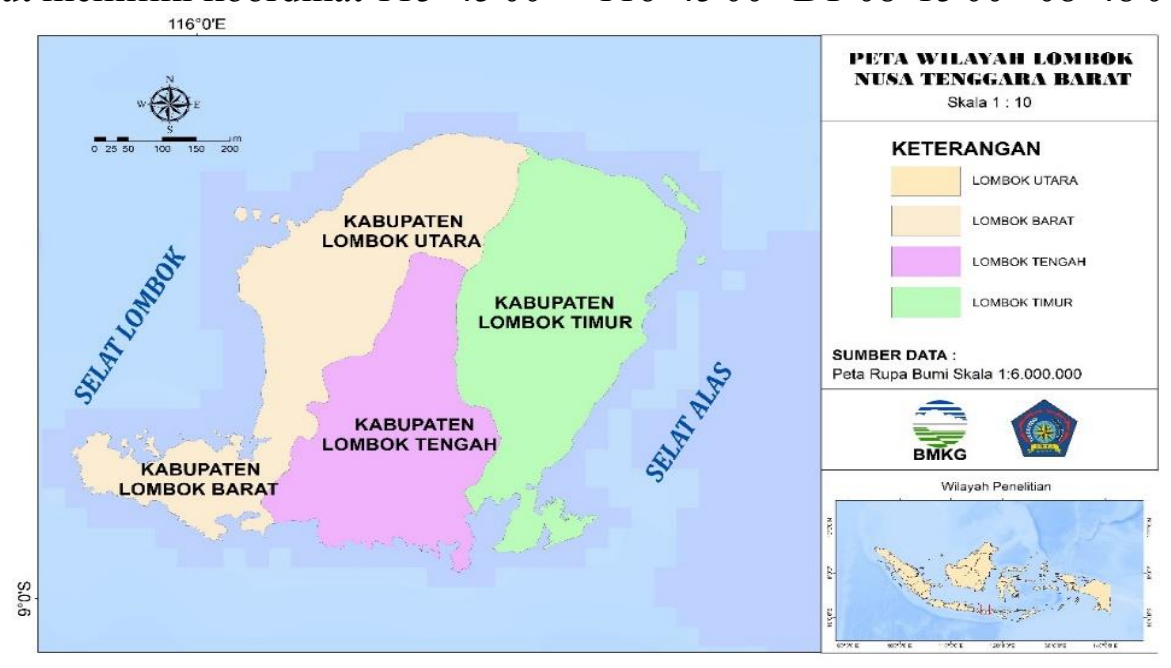

Gambar 2. Lokasi Penelitian 


\section{HASIL DAN PEMBAHASAN}

\subsection{Suhu Permukaan Laut}
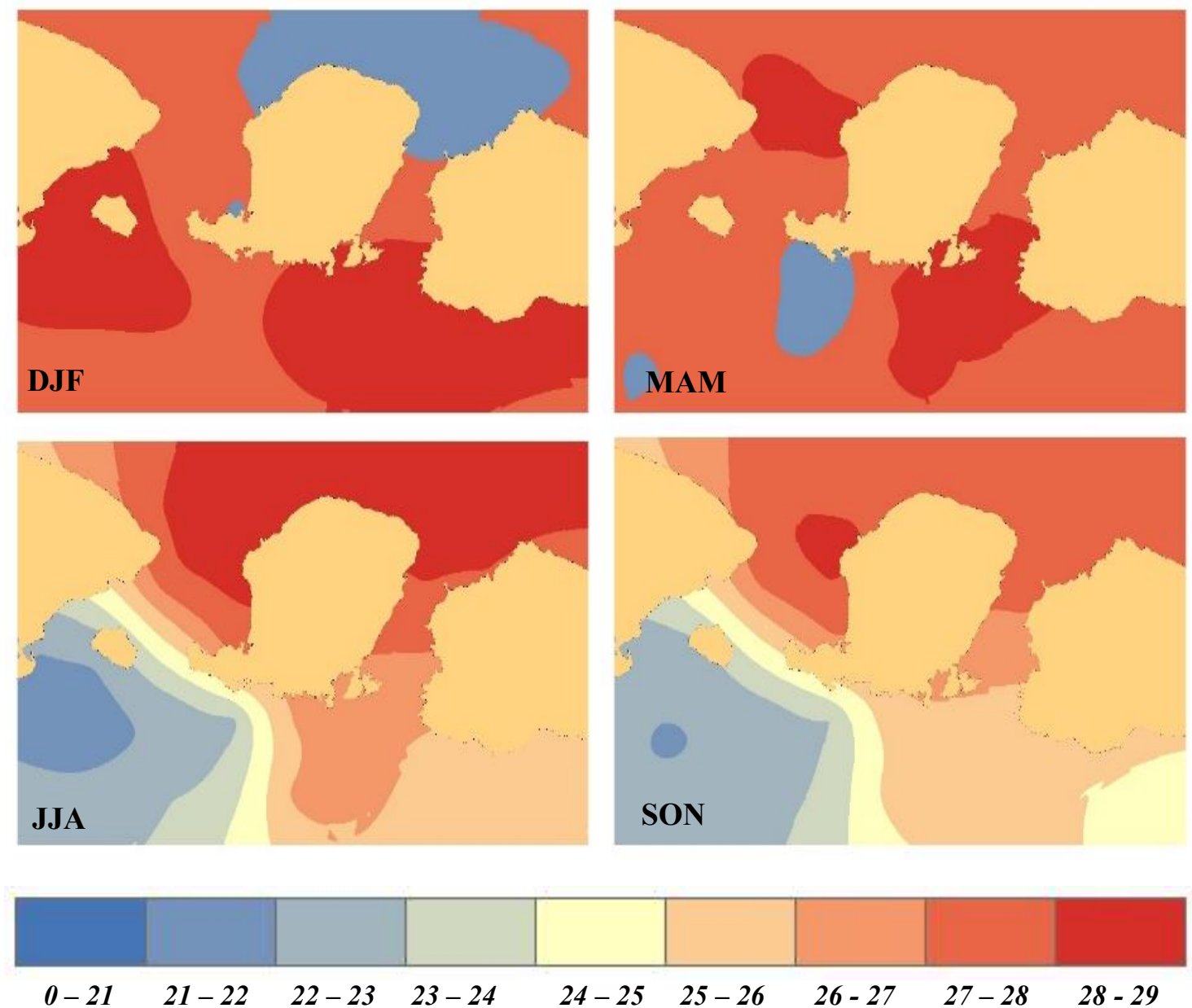

Gambar 3. Pola Musimam Suhu Permukaan Laut di Perairan Lombok $\left({ }^{\circ} \mathrm{C}\right)$

Suhu merupakan salah satu parameter lingkungan yang berpengaruh langsung terhadap organisme terutama dalam mengatur metabolisme tubuh suatu organisme di perairan sehingga berdampak pada pernafasan dan konsumsi oksigen pada organisme. Suhu permukaan laut di Perairan Lombok terdapat perubahan setiap musimnya. Perairan di pesisir Lombok memiliki kondisi suhu berkisar antara $22-29^{\circ} \mathrm{C}$. Nilai suhu perairan pada lokasi penelitian memperlihatkan kisaran yang mendukung untuk kegiatan budidaya kerang mutiara. Indonesia yang beriklim tropis, pertumbuhan yang baik dicapai pada suhu antara $28-30^{\circ} \mathrm{C}$ (Sutaman 1993).

Suhu perairan di pesisir Lombok Utara berkisar antara antara 22 sampai $29^{\circ} \mathrm{C}$. Nilai ini cocok untuk budidaya kerang mutiara yaitu $28-30^{\circ} \mathrm{C}$ ( DKP 2002). Berdasarkan hasil dari pengolahan data citra satelit didapatkan musim yang paling potensial untuk dilakukan budidaya tiram mutiara dengan kriteria suhu $28-30^{\circ} \mathrm{C}$ adalah pada bulan JJA (Juni-JuliAgustus) atau periode musim timur. Dapat dilihat bahwa pada bulan JJA (Juni-Juli-Agustus) wilayah Perairan Lombok memiliki suhu permukaan laut sekitar 25 sampai $29^{\circ} \mathrm{C}$ (warna merah lebih dominan pada JJA). 


\subsection{Kecepatan Arus}
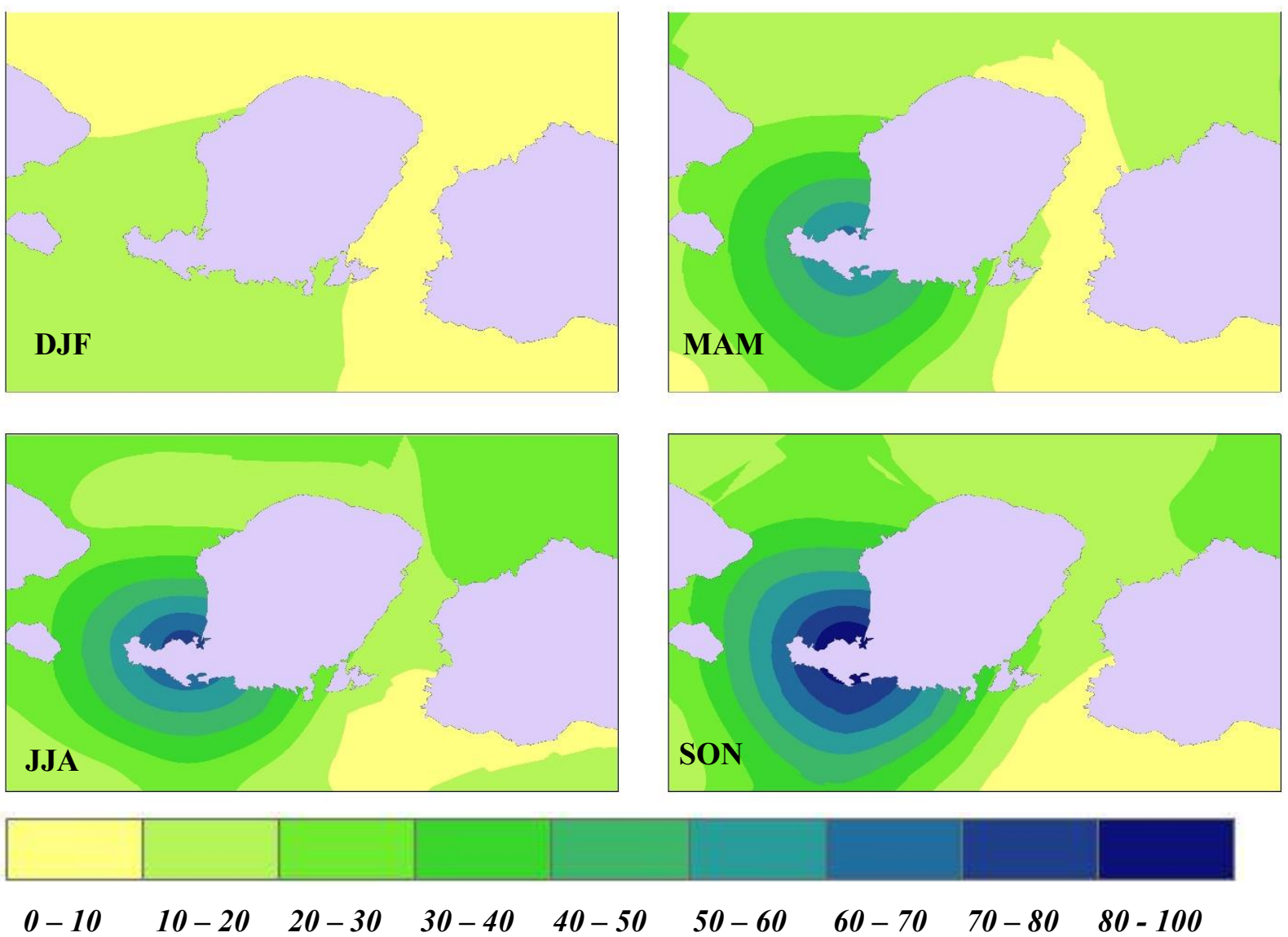

Gambar 3. Pola Musimam Kecepatan Arus Laut di Perairan Lombok (cm/s)

Kecepatan arus laut di Perairan Lombok menunjukan adanya variasi setiap musimnya. Sebaran spasial kecepatan arus di pesisir Lombok berkisar $6-34 \mathrm{~cm} / \mathrm{s}$. Kenaikan kecepatan arus dapat mempersingkat flushing time. Sehingga meningkatkan pasokan partikel makanan (fitoplankton) menjadi lebih banyak karena terbawa oleh arus (Longdill 2008). Kisaran nilai kecepatan arus $6-34 \mathrm{~cm} / \mathrm{s}$ mendukung untuk lokasi budidaya kerang mutiara yaitu sebesar $16-25 \mathrm{~cm} / \mathrm{s}$ (DKP 2002). Adanya turbulensi dan kondisi peraian yang terbuka diduga menjadi perbedaan kuat arus (Perez 2005). Tiram mutiara yang dibudidayakan sangat cocok pada lokasi yang terlindung dari pengaruh angin dan arus yang kuat serta pasang surut yang terjadi dapat menggantikan massa air secara total dan teratur untuk menjamin ketersediaan oksigen terlarut dan plankton (Sutaman 1993). Lokasi dengan arus $19 \mathrm{~cm} / \mathrm{s}$ diduga prospek kegiatan budidaya tiram mutiara akan baik dan menjamin ketersedian makanan.

Berdasarkan hasil pengolahan data kecepatan arus pada bulan JJA merupakan bulan yang potensial daripada bulan - bulan yang lain untuk budidaya tiram mutiara. Karena pada bulan JJA memiliki rentang kecepatan arus $16-25 \mathrm{~cm} / \mathrm{s}$ yang memenuhi kriteria kecepatan arus yang sesuai untuk budidaya tiram mutiara. 


\subsection{Salinitas}
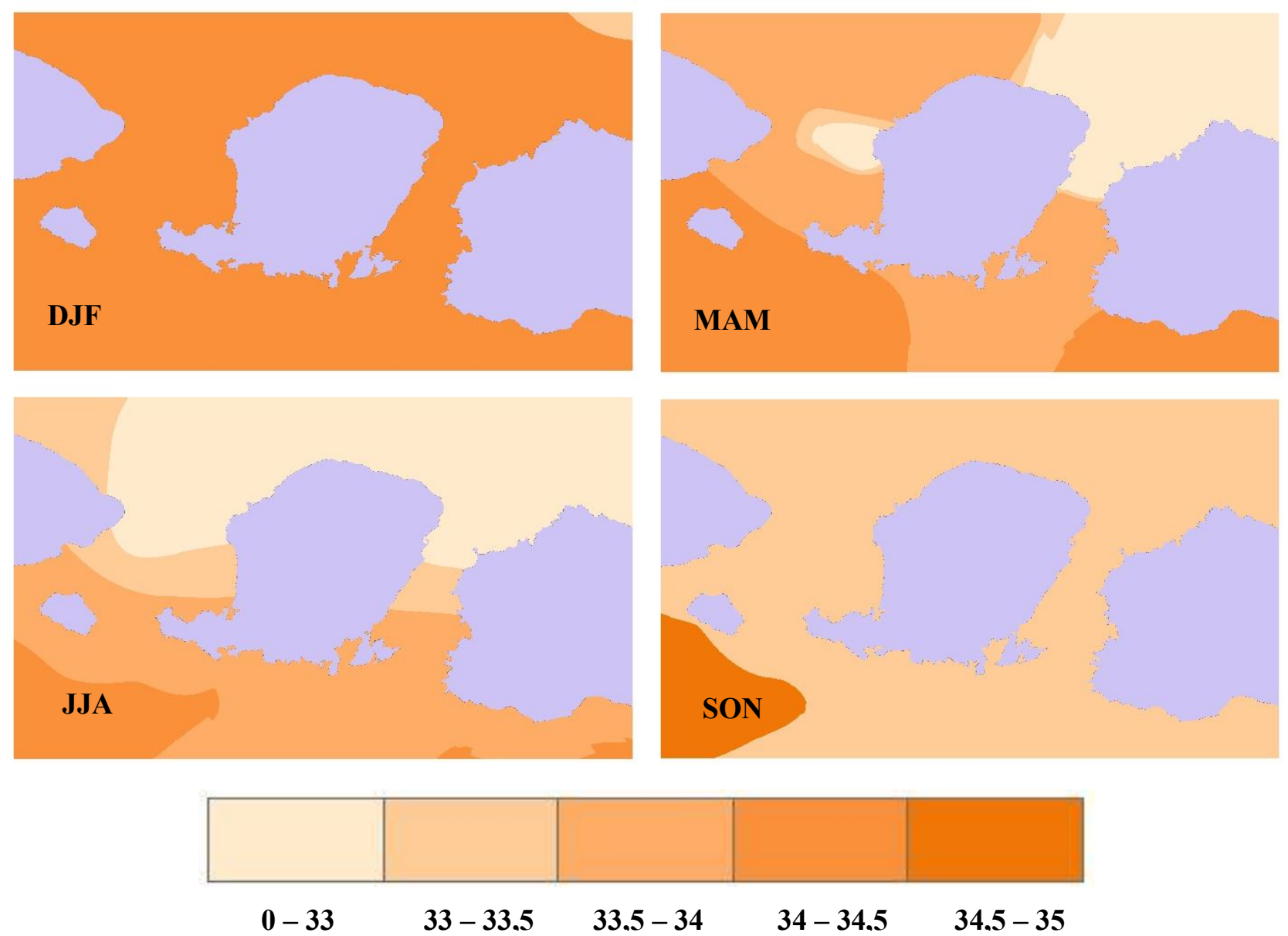

Gambar 6. Salinitas di Perairan Lombok

Sebaran spasial salinitas perairan di perairan Lombok berkisar antara 32-34 ppt. Nilai salinitas perairan pada lokasi penelitian memperlihatkan kisaran yang mendukung untuk budidaya tiram mutiara. Kualitas mutiara yang terbentuk dalam tubuh tiram dapat dipengaruhi oleh kadar salinitas. Pada dasarnya salinitas di bawah 14 ppt atau di atas 35 ppt dapat mengakibatkan kematian tiram yang dipelihara secara massal. Dalam hal ini, tiram mutiara dapat bertahan hidup pada kisaran salinitas yang tinggi berkisar diantara 20-50 ppt, akan tetapi salinitas yang baik untuk pertumbuhan kerang mutiara adalah 32-35 ppt (Sutaman 1993).

Salinitas perairan di Perairan Lombok berkisar antara 32 ppt sampai 34 ppt. Nilai salinitas ini cocok untuk budidaya kerang mutiara yaitu 32-35 ppt (Radiarta 2003). Berdasarkan hasil dari pengolahan data citra satelit didapatkan musim yang paling potensial untuk dilakukan budidaya tiram mutiara dengan kriteria salinitas 32-35 ppt adalah pada semua musim di Perairan Lombok. Karena pada semua bulan DJF, JJA, MAM, SON memiliki salinitas yang sesuai untuk budidaya tiram mutiara. 
Tabel 3. Tabel Sistem Penilaian Kesesuaian Perairan Lombok untuk Lokasi Budidaya Tiram Mutiara

\begin{tabular}{|c|c|c|c|c|c|c|c|c|c|c|c|c|c|c|}
\hline Lintang & Bujur & SST(K) & $\operatorname{SST}\left({ }^{\circ} \mathrm{C}\right)$ & $\begin{array}{l}\text { Nilai } \\
\text { SST }\end{array}$ & $\begin{array}{c}\text { Salinitas } \\
\text { (ppt) }\end{array}$ & $\begin{array}{c}\text { Nilai } \\
\text { Salinitas }\end{array}$ & Arus $\mathrm{V}$ & Arus $U$ & $\begin{array}{c}\text { Kecepatan } \\
(\mathrm{cm} / \mathrm{s})\end{array}$ & $\begin{array}{c}\text { Nilai } \\
\text { Kecepatan }\end{array}$ & $\begin{array}{l}\text { Bobot } \\
\text { Primer }\end{array}$ & $\begin{array}{c}\text { Bobot } \\
\text { Sekunder }\end{array}$ & Skor & IKK \\
\hline-9.5 & 115.25 & 297.952421 & 25 & 3 & 34 & 5 & -0.01801 & -0.08785 & 9 & 1 & 5 & 3 & 29 & 53 \\
\hline-9.5 & 115.75 & 298.658031 & 26 & 3 & 34 & 5 & -0.14648 & -0.17635 & 23 & 5 & 5 & 3 & 49 & 89 \\
\hline-9.5 & 116 & 299.15694 & 26 & 3 & 34 & 5 & -0.16789 & -0.1184 & 21 & 5 & 5 & 3 & 49 & 89 \\
\hline-9.5 & 116.25 & 299.775977 & 27 & 3 & 34 & 5 & -0.03322 & -0.02642 & 4 & 1 & 5 & 3 & 29 & 53 \\
\hline-9.5 & 117 & 299.148526 & 26 & 3 & 34 & 5 & 0.009145 & 0.017721 & 2 & 1 & 5 & 3 & 29 & 53 \\
\hline-9.5 & 117.25 & 299.107273 & 26 & 3 & 34 & 5 & 0.004252 & 0.016979 & 2 & 1 & 5 & 3 & 29 & 53 \\
\hline-9.5 & 117.5 & 299.062903 & 26 & 3 & 34 & 5 & -0.00248 & 0.015491 & 2 & 1 & 5 & 3 & 29 & 53 \\
\hline-9.5 & 117.75 & 299.067037 & 26 & 3 & 34 & 5 & -0.00788 & 0.012636 & 1 & 1 & 5 & 3 & 29 & 53 \\
\hline-9.5 & 118 & 299.088272 & 26 & 3 & 34 & 5 & -0.0146 & 0.009478 & 2 & 1 & 5 & 3 & 29 & 53 \\
\hline-9.25 & 115 & 297.829334 & 25 & 3 & 34 & 5 & 0.01707 & 0.113695 & 11 & 3 & 5 & 3 & 39 & 71 \\
\hline-9.25 & 116.25 & 300.165014 & 27 & 3 & 34 & 5 & -0.11455 & -0.00745 & 11 & 3 & 5 & 3 & 39 & 71 \\
\hline-9.25 & 116.5 & 299.921297 & 27 & 3 & 34 & 5 & -0.01862 & 0.027033 & 3 & 1 & 5 & 3 & 29 & 53 \\
\hline-9.25 & 116.75 & 299.665208 & 27 & 3 & 34 & 5 & 0.006452 & 0.037616 & 4 & 1 & 5 & 3 & 29 & 53 \\
\hline-9.25 & 117 & 299.468169 & 26 & 3 & 34 & 5 & 0.009837 & 0.041359 & 4 & 1 & 5 & 3 & 29 & 53 \\
\hline-9.25 & 117.25 & 299.380306 & 26 & 3 & 34 & 5 & 0.005771 & 0.042398 & 4 & 1 & 5 & 3 & 29 & 53 \\
\hline-9.25 & 117.5 & 299.289228 & 26 & 3 & 34 & 5 & $-4.54 \mathrm{E}$ & 0.040854 & 4 & 1 & 5 & 3 & 29 & 53 \\
\hline-9.25 & 117.75 & 299.239501 & 26 & 3 & 34 & 5 & -0.00703 & 0.03584 & 4 & 1 & 5 & 3 & 29 & 53 \\
\hline-9.25 & 118 & 299.186541 & 26 & 3 & 34 & 5 & -0.01517 & 0.026649 & 3 & 1 & 5 & 3 & 29 & 53 \\
\hline
\end{tabular}




\begin{tabular}{|c|c|c|c|c|c|c|c|c|c|c|c|c|c|c|}
\hline-9 & 115 & 297.900798 & 25 & 3 & 34 & 5 & -0.01763 & 0.169093 & 17 & 5 & 5 & 3 & 49 & 89 \\
\hline-9 & 115.25 & 297.826289 & 25 & 3 & 34 & 5 & $5.45 \mathrm{E}-04$ & 0.178803 & 18 & 5 & 5 & 3 & 49 & 89 \\
\hline-9 & 115.5 & 297.743898 & 25 & 3 & 34 & 5 & 0.00801 & 0.183399 & 18 & 5 & 5 & 3 & 49 & 89 \\
\hline-9 & 115.75 & 297.8294 & 25 & 3 & 34 & 5 & -0.28263 & 0.178077 & 33 & 1 & 5 & 3 & 29 & 53 \\
\hline-9 & 116 & 297.505018 & 25 & 3 & 34 & 5 & -0.44988 & 0.098653 & 46 & 1 & 5 & 3 & 29 & 53 \\
\hline-9 & 116.25 & 300.098385 & 27 & 3 & 34 & 5 & -0.34343 & 0.025323 & 34 & 1 & 5 & 3 & 29 & 53 \\
\hline-9 & 116.5 & 300.09956 & 27 & 3 & 34 & 5 & -0.0681 & 0.030175 & 7 & 1 & 5 & 3 & 29 & 53 \\
\hline-9 & 116.75 & 300.002647 & 27 & 3 & 34 & 5 & $-3.68 E$ & 0.035573 & 4 & 1 & 5 & 3 & 29 & 53 \\
\hline-9 & 117 & 299.863943 & 27 & 3 & 34 & 5 & 0.007546 & 0.040143 & 4 & 1 & 5 & 3 & 29 & 53 \\
\hline-9 & 117.25 & 299.763071 & 27 & 3 & 34 & 5 & 0.005619 & 0.04317 & 4 & 1 & 5 & 3 & 29 & 53 \\
\hline-9 & 117.5 & 299.651219 & 27 & 3 & 34 & 5 & $2.62 \mathrm{E}-04$ & 0.044623 & 4 & 1 & 5 & 3 & 29 & 53 \\
\hline-9 & 117.75 & 299.562527 & 27 & 3 & 34 & 5 & -0.00642 & 0.044355 & 4 & 1 & 5 & 3 & 29 & 53 \\
\hline-9 & 118 & 299.473913 & 26 & 3 & 34 & 5 & -0.01265 & 0.041601 & 4 & 1 & 5 & 3 & 29 & 53 \\
\hline-8.75 & 115 & 297.988783 & 25 & 3 & 34 & 5 & -0.04967 & 0.168619 & 18 & 5 & 5 & 3 & 49 & 89 \\
\hline-8.75 & 115.25 & 297.84779 & 25 & 3 & 34 & 5 & -0.01352 & 0.18186 & 18 & 5 & 5 & 3 & 49 & 89 \\
\hline-8.75 & 115.5 & 297.890314 & 25 & 3 & 34 & 5 & -0.04036 & 0.188539 & 19 & 5 & 5 & 3 & 49 & 89 \\
\hline-8.75 & 116 & 300.250231 & 27 & 3 & 34 & 5 & -0.67015 & 0.108631 & 68 & 1 & 5 & 3 & 29 & 53 \\
\hline-8.5 & 115.75 & 300.958632 & 28 & 5 & 34 & 5 & -0.29063 & -0.03048 & 29 & 3 & 5 & 3 & 45 & 82 \\
\hline-8.5 & 116 & 300.956041 & 28 & 5 & 34 & 5 & -0.31796 & -0.03799 & 32 & 1 & 5 & 3 & 35 & 64 \\
\hline-8.5 & 116.75 & 300.577725 & 28 & 5 & 34 & 5 & -0.00835 & 0.091404 & 9 & 1 & 5 & 3 & 35 & 64 \\
\hline-8.5 & 117 & 300.508046 & 28 & 5 & 34 & 5 & 0.007138 & 0.13865 & 14 & 3 & 5 & 3 & 45 & 82 \\
\hline-8.5 & 117.75 & 300.145183 & 27 & 3 & 34 & 5 & 4.04E-05 & 0.172003 & 17 & 5 & 5 & 3 & 49 & 89 \\
\hline-8.25 & 115.75 & 300.925551 & 28 & 5 & 34 & 5 & -0.13915 & -0.02739 & 14 & 3 & 5 & 3 & 45 & 82 \\
\hline-8.25 & 116 & 300.730382 & 28 & 5 & 34 & 5 & -0.12665 & -0.05214 & 14 & 3 & 5 & 3 & 45 & 82 \\
\hline-8.25 & 116.25 & 300.631006 & 28 & 5 & 34 & 5 & -0.1273 & -0.03817 & 13 & 3 & 5 & 3 & 45 & 82 \\
\hline-8.25 & 116.5 & 300.626562 & 28 & 5 & 34 & 5 & -0.06005 & 0.03301 & 7 & 1 & 5 & 3 & 35 & 64 \\
\hline-8.25 & 116.75 & 300.623669 & 28 & 5 & 34 & 5 & -0.03417 & 0.096807 & 10 & 3 & 5 & 3 & 45 & 82 \\
\hline-8.25 & 117 & 300.641078 & 28 & 5 & 34 & 5 & 0.001034 & 0.150383 & 15 & 3 & 5 & 3 & 45 & 82 \\
\hline-8.25 & 117.25 & 300.616944 & 28 & 5 & 34 & 5 & 0.008061 & 0.17843 & 18 & 5 & 5 & 3 & 55 & 100 \\
\hline-8.25 & 117.5 & 300.650624 & 28 & 5 & 34 & 5 & 0.042862 & 0.217948 & 22 & 5 & 5 & 3 & 55 & 100 \\
\hline
\end{tabular}




\begin{tabular}{ccccccccccccccc}
-8.25 & 117.75 & 300.331018 & 27 & 3 & 34 & 5 & 0.049485 & 0.288256 & 29 & 3 & 5 & 3 & 39 & $\mathbf{7 1}$ \\
-8 & 115 & 300.913759 & 28 & 5 & 34 & 5 & $7.16 \mathrm{E}-04$ & -0.01587 & 2 & 1 & 5 & 3 & 35 & $\mathbf{6 4}$ \\
-8 & 115.25 & 300.960357 & 28 & 5 & 34 & 5 & -0.004 & -0.01259 & 1 & 1 & 5 & 3 & 35 & $\mathbf{6 4}$ \\
-8 & 115.5 & 300.988021 & 28 & 5 & 34 & 5 & -0.04266 & -0.00726 & 4 & 1 & 5 & 3 & 35 & $\mathbf{6 4}$ \\
-8 & 115.75 & 300.975908 & 28 & 5 & 34 & 5 & -0.08917 & -0.02997 & 9 & 1 & 5 & 3 & 35 & $\mathbf{6 4}$ \\
-8 & 116 & 300.862531 & 28 & 5 & 34 & 5 & -0.09048 & -0.06371 & 11 & 3 & 5 & 3 & 45 & $\mathbf{8 2}$ \\
-8 & 116.25 & 300.720509 & 28 & 5 & 34 & 5 & -0.09495 & -0.04912 & 11 & 3 & 5 & 3 & 45 & $\mathbf{8 2}$ \\
-8 & 116.5 & 300.709958 & 28 & 5 & 34 & 5 & -0.08924 & 0.006174 & 9 & 1 & 5 & 3 & 35 & $\mathbf{6 4}$ \\
-8 & 116.75 & 300.714389 & 28 & 5 & 34 & 5 & -0.08285 & 0.065547 & 11 & 3 & 5 & 3 & 45 & $\mathbf{8 2}$ \\
-8 & 117 & 300.774795 & 28 & 5 & 34 & 5 & -0.05137 & 0.121171 & 13 & 3 & 5 & 3 & 45 & $\mathbf{8 2}$ \\
-8 & 117.25 & 300.788069 & 28 & 5 & 34 & 5 & -0.01382 & 0.180584 & 18 & 5 & 5 & 3 & 55 & $\mathbf{1 0 0}$ \\
-8 & 117.5 & 300.835055 & 28 & 5 & 34 & 5 & 0.016793 & 0.253344 & 25 & 5 & 5 & 3 & 55 & $\mathbf{1 0 0}$ \\
-8 & 117.75 & 300.580751 & 28 & 5 & 34 & 5 & 0.117065 & 0.326432 & 35 & 1 & 5 & 3 & 35 & $\mathbf{6 4}$ \\
-8 & 118 & 300.162132 & 27 & 3 & 34 & 5 & 0.040284 & 0.335154 & 34 & 1 & 5 & 3 & 29 & $\mathbf{5 3}$ \\
\hline
\end{tabular}

IKK = Indeks Kesesuaian Kawasan

Keterangan:

$\begin{array}{lll}85-100 \% & \text { S1 } & \text { Sangat sesuai } \\ 75-<85 \% & \text { S2 } & \text { Sesuai } \\ <65-74 \% & \text { S3 } & \text { Tidak sesuai }\end{array}$




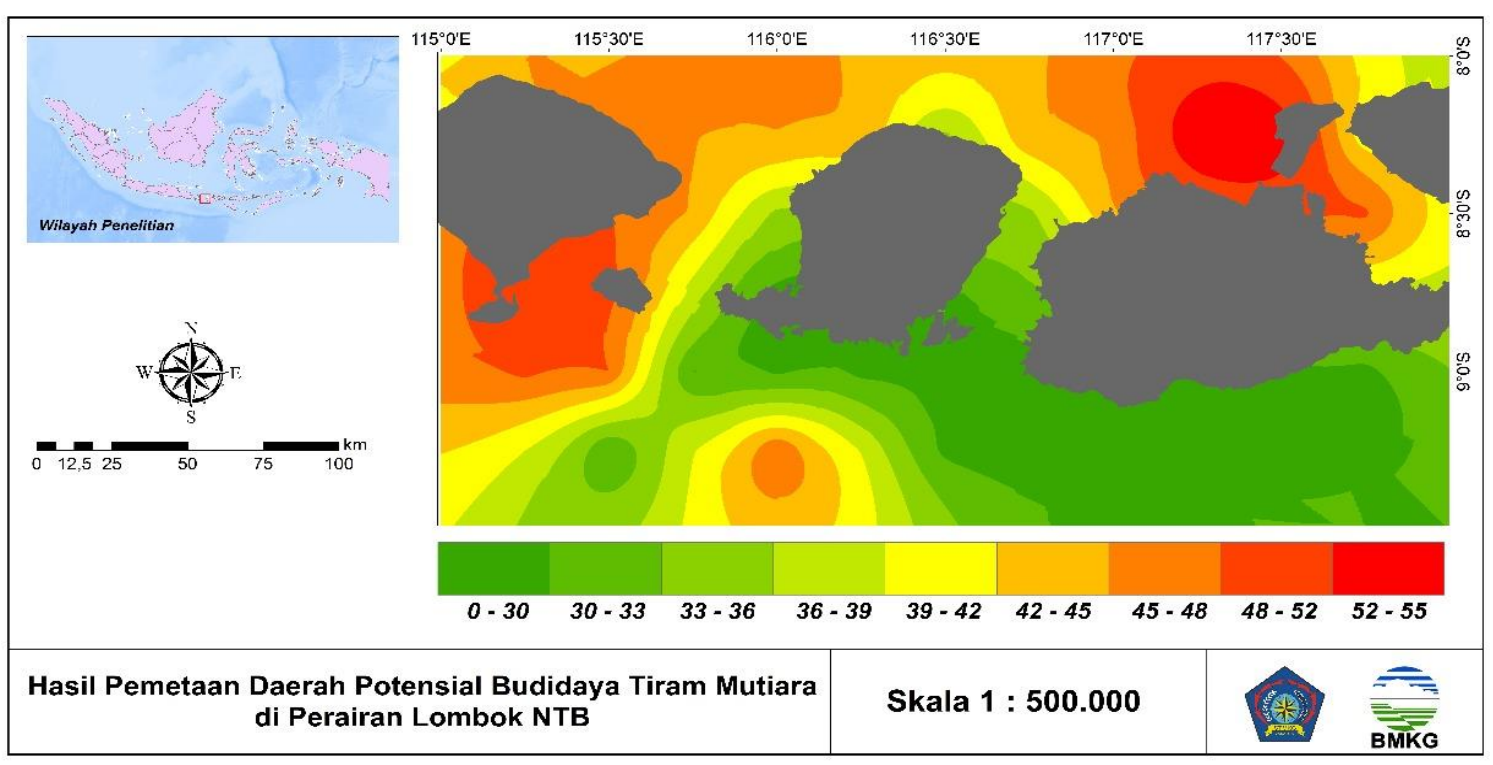

Gambar 7. Pemetaan Daerah Potensial Budidaya Tiram Mutiara di Perairan Lombok

Berdasarkan tabel dan gambar diatas Perairan Lombok merupakan wilayah sesuai untuk usaha budidaya tiram mutiara. Hal tersebut dapat ditunjukkan oleh nilai scoring yang sesuai untuk budidaya tiram mutiara yaitu dengan rata - rata masuk kedalam S2 yang berarti sesuai untuk budidaya tiram mutiara.

Daerah yang paling potensial untuk budidaya tiram mutiara yaitu di Perairan sebelah Timur Laut dan Barat di Perairan Pulau Lombok atau kawasan Pesisir Timur Laut dan Barat Pulau Lombok. Perairan Lombok Utara memiliki skor tertinggi dan masuk kedalam rentang S2 atau sesuai untuk budidaya tiram mutiara. Hal ini juga disebabkan karena pada daerah pesisir Perairan Lombok Utara memiliki parameter hidrometeorologi (kecepatan arus laut, suhu permukaan laut, dan salinitas) yang sesuai untuk budidaya tiram mutiara. Gambar dan tabel diatas (Tabel 3. Dan Gambar 6.) merupakan hasil skoring seluruh parameter hidrometeorologi yang berupa kecepatan arus laut, suhu permukaan laut, dan salinitas. Sehingga secara umum peta tersebut dapat digunakan sebagai acuan dalam penentuan lokasi untuk budidaya tiram mutiara di Perairan Lombok dengan memerhatikan faktor suhu permukaan laut, kecepatan arus laut, dan salinitas.

\section{KESIMPULAN}

1. Berdasarkan analisis parameter hidrometeorologi yang berupa kecepatan arus, suhu permukaan laut, dan salinitas dengan menggunakan data citra satelit selama 10 tahun (2006 - 2016) dapat disimpulkan bahwa daerah sekitar Perairan Lombok, Nusa Tenggara Barat adalah daerah yang cocok untuk budidaya tiram mutiara.

2. Berdasarkan analisis parameter hidrometeorologi yang berupa kecepatan arus, suhu permukaan laut, dan salinitas yang dibagi sesuai periode bulan DJF, MAM, JJA, SON dengan menggunakan data citra satelit dapat disimpulkan bahwa secara umum lokasi yang paling potensial untuk dilakukan pengembangan budidaya tiram mutiara adalah daerah pesisir sebelah Timur Laut dan Barat Pulau Lombok (Perairan Lombok Utara dan Lombok Barat). Hal ini dapat dilihat dari data selama 10 tahun (2006 - 2016) dengan pada periode bulan DJF, MAM, JJA, SON bahwa daerah tersebut menunjukan rentang yang sesuai (S2) dan memiliki rata - rata 
skor yang tertinggi daripada daerah lainnya. Sehingga daerah tersebut berpotensi untuk dikembangan oleh masyarakat dalam budidaya tiram mutiara di sekitar Perairan Lombok, Nusa Tenggara Barat.

3. Secara khusus dilihat dari masing - masing parameter hidrometeorologi yang dikaji didapatkan periode atau musim yang paling baik untuk dimanfaatkan oleh pembudidaya tiram mutiara dalam memulai proses budidayanya, yaitu pada periode bulan JJA (Juni-Juli-Agustus).

\section{UCAPAN TERIMA KASIH}

Terima kasih kepada Ibu Asri Susilawati selaku dosen praktek satelit cuaca beserta temanteman seperjuangan yang telah memberikan semangat, motivasi, dan bantuan ilmunya pada penulis dalam menyusun karya ini. Untuk pihak-pihak yang tidka bisa disebutkan di sini terima kasih atas bantuannya sehingga karya ini dapat terselesaikan.

\section{DAFTAR PUSTAKA}

Hmzah, M. S. dan Nababan Bisman, 2011. Pengaruh Musim dan Kedalaman terhadap Pertumbuhan dan Kelangsungan Hidup Kerang Mutiara (Pinctada maxima) di Teluk Kodek, Lombok Utara. Jurnal Ilmu dan

Teknologi Kelautan Tropis, Vol. 3 No. 2 Hal. 48-61.

Jamilah, 2015. Analisis Hidro-Oseanografi untuk Budidaya Tiram Mutiara di Perairan Baubau. Jurnal Biotek

Vol. 3 No.2.

Kotta, Raismin, 2018. Teknik Pembenihan Tiram Mutiara Pinctada Maxima. Prosiding Seminar Nasional

KSP2K II, 1 (2) : 228 - 244.

Spj, Nur Taufik, dkk., 2007. Pertumbuhan Tiram Mutiara (Pinctada maxima) pada Kepadatan Berbeda. Ilmu Kelautan, Vol. 12 (1) : 31 - 38.

Sudewi, dkk., 2010. Pendederan Tiram Mutiara, Pinctada Maxima dengan Perbedaan Kedalaman. Jurnal Perikanan (J. Fish. Sci.) XII (2): 57-63.

Sutaman, 2000. Tiram Mutiara: Teknik Budidaya \& Proses Pembuatan Mutiara. Kanisius, Yogyakarta.

Tomatala, Pitjont, 2011. Pengaruh Suhu terhadap Pemijahan Kerang Mutiara Pinctada Maxima. Jurnal Perikanan dan Kelautan Tropis, Vol. VII-1. 